\title{
Impact of Selected Abiotic Components on the Variability of Macrobenthic Community Structure in Small Watercourses
}

\author{
Adam Brysiewicz ${ }^{1 *}$, Maria Wolska², Przemysław Czerniejewski ${ }^{3}$, \\ Anna Wojciechowska ${ }^{4}$ \\ ${ }^{1}$ Institute of Technology and Life Sciences, Falenty, Poland \\ ${ }^{2}$ West Pomeranian University of Technology, Department of Hydrobiology, Ichthyology \\ and Biotechnology of Reproduction, Szczecin, Poland \\ ${ }^{3}$ West Pomeranian University of Technology, Department of Fisheries Management \\ and Water Protection, Szczecin, Poland \\ ${ }^{4}$ Nicolas Copernicus University, Faculty of Biology and Environmental Protection, \\ Chair of Geo-botany and Landscape Planning, Torun, Poland
}

Received: 12 June 2018

Accepted: 4 September 2018

\begin{abstract}
The current study analyzes the impact of physico-chemical and hydrological components on taxonomic diversity, density and Shannon's diversity index for micro-benthic communities found in small lowland rivers. The purpose of this study was to determine major predictors among environmental factors that have an impact on benthic invertebrate communities dwelling in small rivers, and to compare the structure of the communities in terms of their abundance, biodiversity and abundance between the sites. For this purpose we studied a total of 30 sites located in 10 watercourses, where 95 taxa were identified, including 49 specific species. The study brought evidence of differences in the number of taxa, biodiversity indices and abundance of micro-benthic communities across specific sites. Ammonium ions, water velocity and phosphates were found to be major predictors among environmental factors having impact on benthic communities.
\end{abstract}

Keywords: benthic invertebrates, small rivers, anthropopressure, environmental factors

\section{Introduction}

Water resources in small catchment areas are particularly important in view of the need to efficiently manage disposable water resources, which are quite

*e-mail: a.brysiewicz@itp.edu.pl minor in Poland [1]. Rivers located in land used for agricultural purposes are subject to strong anthropogenic impact [2]. Small watercourses are particularly sensitive to rapid and short-term discharge of nutrients from agricultural land, and individual groups of aquatic organisms may respond to changes in their habitats in a highly diversified manner [3]. The variable water quality parameters in these watercourses considerably affect the community structure and abundance of 
specific species. Overgrowing and siltation, as well as procedures involving morphological transformations of small watercourses in the land used for agricultural purposes, also essentially affect the diversity of species dwelling in rivers.

Significant deterioration in the water quality in the rivers along with dramatic biodiversity loss has posed serious threats to the hydrological and ecological balance in freshwater eco-systems [4]. In accordance with the Water Framework Directive, the EU countries are expected to have ensured good ecological and chemical status of surface waters [5]. In order to determine the type and scope of environmental stress effects, the water quality assessment system was unified across all member states, and an obligation to monitor biotic components such as fish fauna, zoo-benthos, phytoplankton and macrophytes was imposed. The directive further imposed an obligation to conduct end-to-end analyses of all available ecological data characteristic for rivers, regarding environmental parameters [5]. One of the projects is the Science and Management of Intermittent Rivers \& Ephemeral Streams (SMIRES), which aims to develop a multi-disciplinary network of scientists and stakeholder experts on intermittent rivers and ephemeral streams (IRES) from 27 countries in order to consolidate and expand the current understanding of IRES and translate it into sciencebased, sustainable management of IRES resources and biodiversity.

Because of their sensitivity to environmental changes, benthic macroinvertebrates have often been used for assessing the ecological status of different water bodies, and for assessing surface water quality [6-10]. Physical and chemical parameters of water
[11-12], its level and velocity [13], bottom type and type of mineral and organic matter [11, 14] are highly important for establishing the representativeness of different macrobenthic communities in rivers.

Despite numerous scientific publications on benthic communities dwelling in rivers [6-7, 15-16], knowledge about benthic community structure and its relationship with environmental parameters in small watercourses has been scarce due to their environmental instability.

This paper puts forward a hypothesis that environmental conditions determine the structure of benthic invertebrate communities in small rivers. The purpose of this study was: 1) to identify major predictors among environmental factors having an impact on benthic invertebrate communities in small rivers; 2) to compare community structures in terms of species abundance, biodiversity index and density across the sites; and 3) to provide basic data for controlling activities essential to implement a coherent water resources management plan.

\section{Materials and Methods}

\section{Study Area}

The study was conducted in 10 small rivers in two Polish regions (five rivers in the northwest and five rivers in central Poland) (Fig. 1). For each river, three study sites were established. Each of the tested watercourses was divided into three representative sites, differing in character (natural and anthropogenically changed watercourses) and selected abiotic features (bottom type, water flow, and depth).

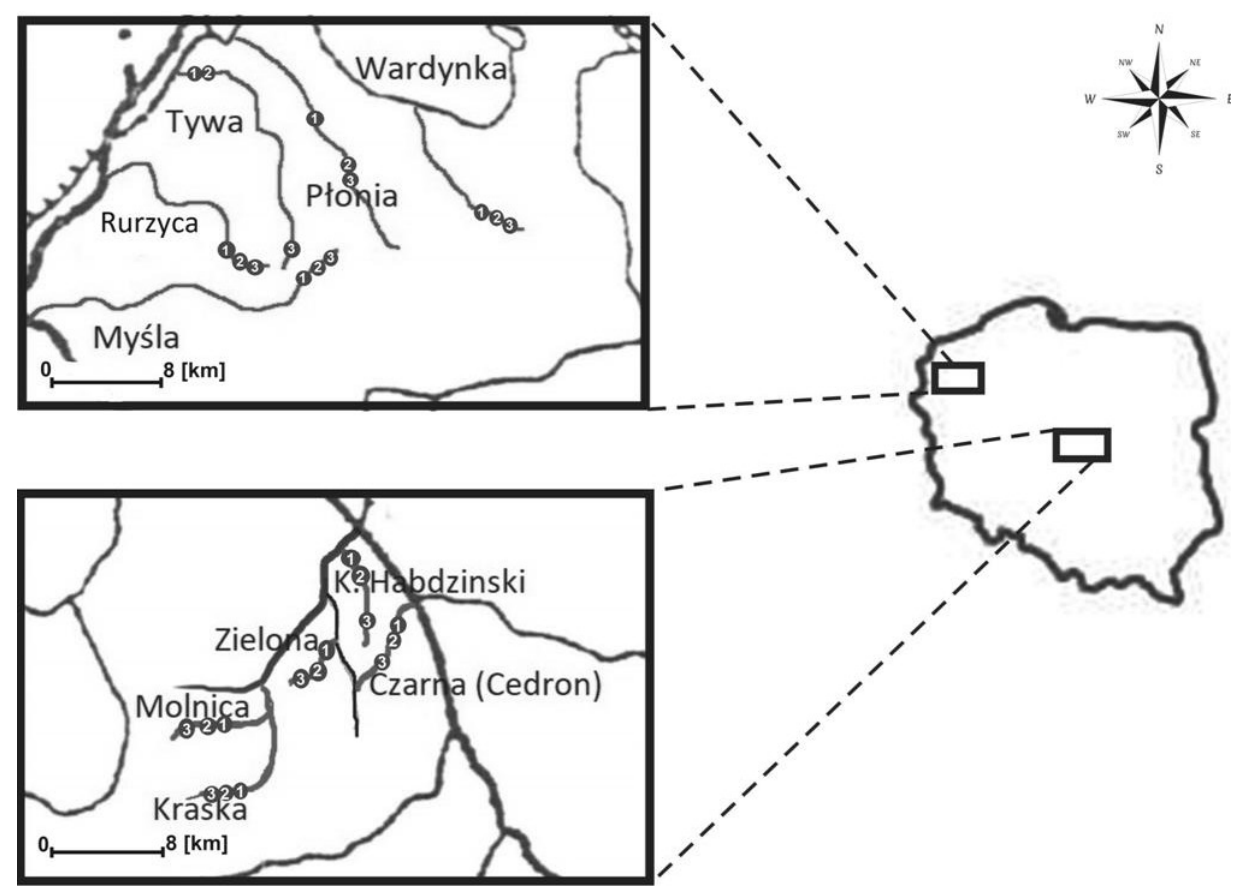

Fig. 1. Study site locations. 


\section{Macroinvertebrate Sampling}

Macrobenthic samples were collected in autumn (October) 2017 using a dragnet of $0.20 \times 0.35 \mathrm{~m}$, with mesh of $500 \mu \mathrm{m}$, scraping off a fragment of the bottom of $1.5 \mathrm{~m}$ in length. A total of 30 samples were collected. Each sample was washed on a screen (mesh of $500 \mu \mathrm{m})$ and preserved using $10 \%$ formaldehyde solution. Labelled and counted invertebrates were assigned to the lowest possible taxon. In the case of a large number of specimens per species, a sub-sampling technique was used, whereas in the case of large and sparse organisms, all specimens were selected from the sample.

\section{Water Sampling}

Using a HACH multi-parameter portable meter (HQ40D), we measured the temperature and $\mathrm{pH}$ of the water, as well as dissolved oxygen content directly in the field. At the same time, water samples of $1 \mathrm{dm}^{3}$ were collected to analyze nitrate, ammonium and orthophosphate content.-Laboratory measurements were based on colorimetric methods and conducted with a HACH DR 890 spectrophotometer. Water flow velocity was measured using a SENSA RC2 electro-magnetic meter equipped with an RV2 velocity probe.

\section{Data Analysis}

Benthic communities were described using basic parameters of ecological communities, such as the number of taxa, dominant species and frequency. Biodiversity in the studied river areas was calculated using the Shannon-Wiener diversity index $\left(\mathrm{H}^{\prime}\right)$. The correspondence variate analysis (CVA) was performed in order to find out which abiotic components determined significant differences between the examined rivers. Along with the analysis, the Monte Carlo permutation test and forward selection of variables were performed in order to identify parameters diversifying the studied rivers in a statistically significant manner. As all indices showed that substrate had no significant impact on the distribution of taxa/sites in the ordination space, and the large amount of information made the diagram illegible, they were excluded from the analysis, and only data related to physico-chemical water components were included. Analysis was performed using Canoco 5.0 software [17].

The second applied ordination technique was canonical correspondence analysis (CCA). Ultimately, for the same reasons as in the case of CVA, data concerning the substrate were excluded from the analysis, which was intended to determine the relationship between species and chemical parameters. The Monte Carlo permutation test and forward selection of variables also were performed in this case. Both analyses were performed using Canoco 5.0 software [17].
The result of both ordination analyses were the ordination diagrams on which geometrical symbols were marked with research stands (rivers in CVA and CCA) or species (CCA). Using chemical vectors, chemical parameters were determined as environmental variables. The longer the vector, the greater its significance for the diversity in the set. The mutual position of the vectors indicates their relations (the closer to each other, the greater the correlation between the variables). The position of the point marking a given station near the arrowhead of the vector means a relatively high value of the variable determined by the vector in a given place

\section{Results}

\section{Chemical and Physical Properties of Water}

Water analyses performed at the study sites (Table 1) and rivers showed considerable differences in physico-chemical water parameters. Correspondence variate analysis (CVA) showed that the rivers differed significantly in terms of nitrate ion content, $\mathrm{pH}$, conductivity, dissolved oxygen content and temperature (Fig. 2). The highest dissolved oxygen and $\mathrm{NO}_{3}$ nitrate ion contents were recorded for the Molnica and Wardynka rivers, whereas rivers with low nitrate ion content had higher average temperature and $\mathrm{pH}$ of the waters (Rurzyca, Myśla, Tywa). The Kraska River, characterised by high average water conductivity, was reported to have the lowest ammonium ion content, whereas the Czarna, Zielona rivers and Habdziński Canal are characterised by higher ammonium ion content and the lowest conductivity.

\section{Macroinvertebrate}

The analysis of macrobenthic communities in the studied rivers confirmed the presence of specimens belonging to the following major taxonomic classes (listed in descending order in terms): Oligochaeta $24 \%$, Bivalvia $22 \%$, Insecta $21 \%$, Gastropoda $16 \%$, Crustacea $13 \%$, and Hirudinea 4\%, as well as Enthognatha and Desmospongiae (both less than $0.5 \%$ ).

In benthic communities found in the studied rivers, 95 taxa were identified, including 49 species, 23 genera, 21 families and two higher taxonomic ranks. Taxa displaying the highest frequency included representatives of the Enchytraeidae (Oligochaeta) family that inhabited $73 \%$ of the sites and Pisidium spp. (Bivalvia) reported in $70 \%$ of sites, which are widespread in temperate regions. The vast majority of Pisidium representatives were young specimens that could not be identified in a reliable manner due to poorly developed taxonomic characteristics. Among mature specimens, Pisidium amnicum (Müller) was identified, among many others. Subsequent representatives with a relatively high frequency were Planorbis corneus (L.) and Radix labiata (Rossmässler), with each species inhabiting 43\% 
Table 1. Select hydro-chemical and physical parameters of the studied rivers.

\begin{tabular}{|c|c|c|c|c|c|c|c|c|c|}
\hline Watercourses & $\begin{array}{l}\text { Position and } \\
\text { designation }\end{array}$ & $\begin{array}{c}\text { Current } \\
\text { velocity } \\
{[\mathrm{m} / \mathrm{s}]}\end{array}$ & $\begin{array}{c}\text { Water } \\
\text { temperature } \\
{\left[{ }^{\circ} \mathrm{C}\right]}\end{array}$ & $\mathrm{pH}$ & $\begin{array}{c}\text { Conductivity } \\
{\left[\mu \mathrm{S} \cdot \mathrm{cm}^{-1}\right]}\end{array}$ & $\begin{array}{c}\mathrm{O}_{2} \\
{\left[\mathrm{mg} \cdot \mathrm{dm}^{3}\right]}\end{array}$ & $\begin{array}{c}\mathrm{N}-\mathrm{NO}_{3} \\
{\left[\mathrm{mg}^{3} \mathrm{dm}^{3}\right]}\end{array}$ & $\begin{array}{c}\mathrm{N}-\mathrm{NH}_{4} \\
{\left[\mathrm{mg} \mathrm{dm}^{3}\right]}\end{array}$ & $\begin{array}{c}\mathrm{P}_{-\mathrm{PO}_{4}} \\
{\left[\mathrm{mg}^{\cdot} \mathrm{dm}^{3}\right]}\end{array}$ \\
\hline \multirow{3}{*}{ Płonia } & $\mathrm{P} 1$ & 0.89 & 18.9 & 7.58 & 729 & 1.97 & 5.60 & 0.09 & 1.40 \\
\hline & P2 & 0.30 & 18.2 & 7.80 & 617 & 2.80 & 4.65 & 0.07 & 1.08 \\
\hline & $\mathrm{P} 3$ & 0.31 & 16.6 & 7.85 & 615 & 2.44 & 5.04 & 0.11 & 0.81 \\
\hline \multirow{3}{*}{ Myśla } & My1 & 0.14 & 19.5 & 7.96 & 636 & 1.9 & 3.13 & 0.12 & 0.44 \\
\hline & My2 & 0.14 & 19.8 & 7.60 & 750 & 2.2 & 10.60 & 0.03 & 0.90 \\
\hline & My3 & 0.02 & 19.9 & 7.49 & 677 & 7.29 & 1.96 & 0.06 & 1.34 \\
\hline \multirow{3}{*}{ Tywa } & $\mathrm{T} 1$ & 0.85 & 19.0 & 7.97 & 612 & 4.45 & 4.90 & 0.08 & 0.46 \\
\hline & $\mathrm{T} 2$ & 0.68 & 19.0 & 8.00 & 606 & 3.45 & 5.26 & 0.09 & 0.68 \\
\hline & $\mathrm{T} 3$ & 0.18 & 19.3 & 7.63 & 852 & 2.11 & 11.93 & 0.08 & 0.50 \\
\hline \multirow{3}{*}{ Rurzyca } & $\mathrm{R} 1$ & 0.64 & 19.9 & 7.66 & 691 & 4.56 & 4.27 & 0.14 & 0.72 \\
\hline & $\mathrm{R} 2$ & 0.64 & 19.4 & 7.64 & 629 & 3.83 & 3.57 & 0.12 & 0.99 \\
\hline & $\mathrm{R} 3$ & 0.58 & 19.2 & 7.71 & 663 & 2.32 & 0.29 & 0.13 & 0.72 \\
\hline \multirow{3}{*}{ Wardynka } & W1 & 0.52 & 15.5 & 7.54 & 548 & 3.14 & 5.29 & 0.06 & 0.82 \\
\hline & W2 & 1.72 & 13.6 & 7.54 & 547 & 9.45 & 5.62 & 0.06 & 0.59 \\
\hline & W3 & 0.51 & 14.0 & 7.20 & 375 & 4.16 & 3.26 & 0.04 & 0.94 \\
\hline \multirow{3}{*}{$\begin{array}{c}\text { Kanał } \\
\text { Habdziński }\end{array}$} & KH1 & 0.03 & 18.5 & 7.08 & 609 & 2.16 & 7.50 & 0.16 & 0.64 \\
\hline & $\mathrm{KH} 2$ & 0.08 & 19.0 & 7.08 & 628 & 2.66 & 6.67 & 0.73 & 0.82 \\
\hline & KH3 & 0.02 & 19.1 & 6.96 & 565 & 3.19 & 6.72 & 0.07 & 0.70 \\
\hline \multirow{3}{*}{ Zielona } & $\mathrm{Z1}$ & 0.14 & 18.5 & 7.53 & 568 & 9.73 & 22.13 & 0.05 & 0.78 \\
\hline & $\mathrm{Z} 2$ & 0.30 & 18.3 & 7.41 & 490 & 8.40 & 19.50 & 0.10 & 0.75 \\
\hline & $\mathrm{Z3}$ & 0.20 & 17.8 & 7.30 & 553 & 6.50 & 2.34 & 0.09 & 0.80 \\
\hline \multirow{3}{*}{$\begin{array}{l}\text { Czarna } \\
\text { (Cedron) }\end{array}$} & $\mathrm{C} 1$ & 0.33 & 18.9 & 7.31 & 535 & 5.41 & 7.16 & 0.11 & 0.54 \\
\hline & $\mathrm{C} 2$ & 0.01 & 18.8 & 7.21 & 540 & 4.25 & 7.76 & 0.10 & 0.85 \\
\hline & $\mathrm{C} 3$ & 0.02 & 20.1 & 7.23 & 533 & 5.15 & 8.78 & 0.10 & 0.40 \\
\hline \multirow{3}{*}{ Kraska } & $\mathrm{K} 1$ & 0.09 & 17.2 & 7.55 & 849 & 6.74 & 12.96 & 0.08 & 0.56 \\
\hline & $\mathrm{K} 2$ & 0.02 & 16.9 & 7.60 & 871 & 8.55 & 12.03 & 0.07 & 0.57 \\
\hline & $\mathrm{K} 3$ & 0.07 & 16.8 & 7.62 & 894 & 6.64 & 9.32 & 0.12 & 0.80 \\
\hline \multirow{3}{*}{ Molnica } & Mo1 & 0.01 & 15.7 & 7.45 & 782 & 5.53 & 22.35 & 0.12 & 0.79 \\
\hline & Mo2 & 0.01 & 14.4 & 7.45 & 775 & 8.14 & 19.99 & 0.10 & 0.62 \\
\hline & Mo3 & 0.03 & 14.2 & 7.26 & 761 & 7.59 & 8.25 & 0.06 & 0.42 \\
\hline
\end{tabular}

of the sites. As many as 39 taxa were very rare (only at a single site with low density). Numbers of taxa identified at the sites varied (from 3 to 25) (Fig. 3a). The highest density was recorded at $\mathrm{C} 1$ site (Fig. 3b). The most abundant species belonged to the class Gastropoda, mainly Pisidium spp. (50\%), Valvata piscinalis O.F.M. (9.5\%), Musculium lacustre O.F.M. (7.9\%), Bithynia tentaculata (L.) (7.1\%), Sphaerium Scopoli (6.3\%), and Anisus leucostoma (Millet) (1.6\%), as well as crustaceans Asellus aquaticus (L.) (8.7\%) and representatives of oligochaetes Lumbriculidae (4.8\%). At the second site with the highest density, $\mathrm{KH} 2$, the prevailing group were species of the subclass Oligochaeta: Aelosomatidae 45.3\%, Enchytraeidae 11.3\%, Chaetogaster sp. Baer 6.8\%, Tubificidae 4.5\%. Gastropods Planorbis corneus (L.) and isopod crustaceans Asellus aquaticus (L.) also had a significant share: $8.2 \%$ and $10 \%$ respectively. At the site with the lowest density (Z1), benthic fauna was mainly composed of insect larvae: Diptera - Simulim sp. Latreille (40.9\%) and Polypedilum sp. Kieffer (9.1\%), 


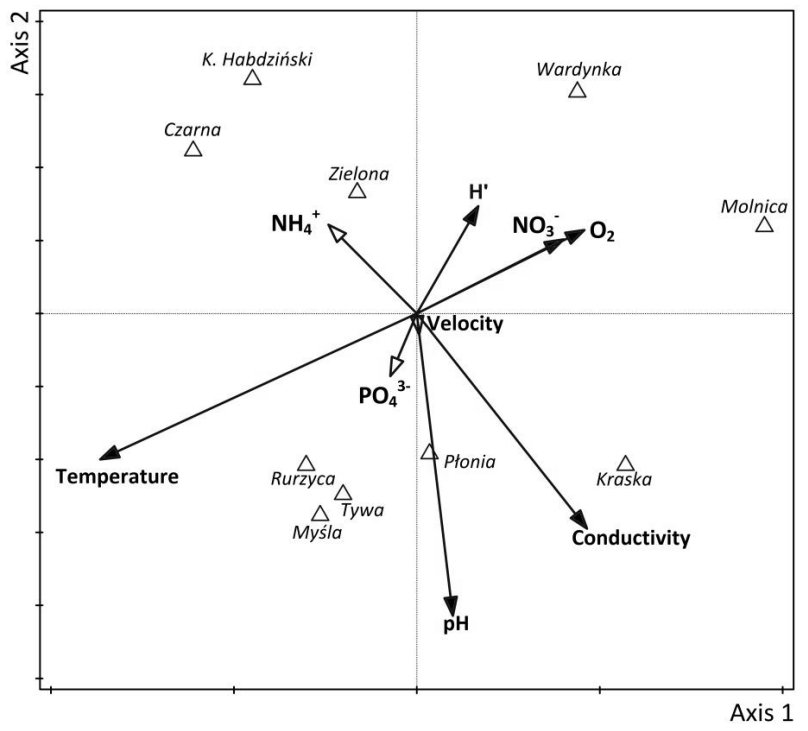

Fig. 2. CVA of physico-chemical parameters of examined rivers; variables with senses of the vectors marked in red are statistically significant for biodiversity in the set; in total, these variables account for $39.2 \%$ of total data variability.
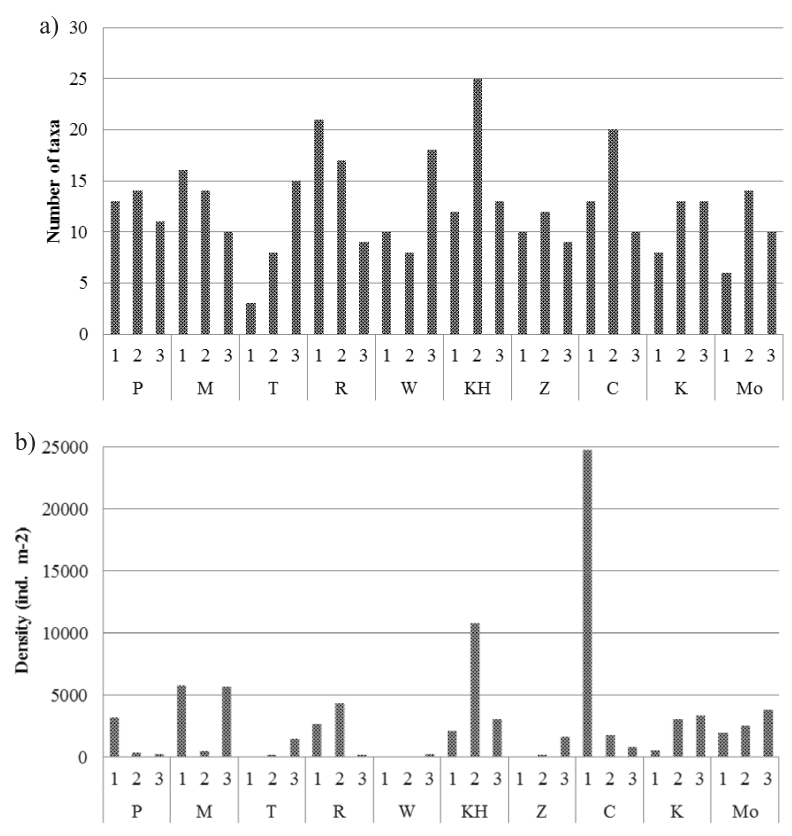

c)

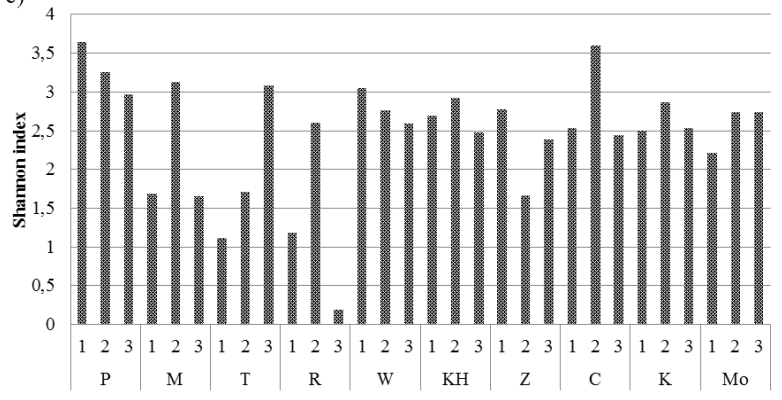

Fig. 3. Taxa number a), abundance (inds. $\mathrm{m}^{-2}$ ) b) and Shannon index $\left(\mathrm{H}^{\prime}\right) \mathrm{c}$ ) of benthic invertebrates of the rivers studied.
Trichoptera - Hydropsychidae (13.6\%) and oligochaetes Chaetogaster sp. Baer (9.1\%). Sites where density of benthic organisms were the highest were dominated by taxa highly tolerant of environmental pollution (among others Asellus aquaticus, Planorbis corneus, representing the Lumbriculidae family). At sites with clearly more favourable environmental conditions on the other hand, composition of benthic communities was different. For example, the prevailing species at W2 site were: amphipod crustacean Gammarus roeselli Gervais, which accounted for 34.7\%, Ephemeroptera larvae: Baetidae and Ephemera sp. L. (16.3\% and 8.2\% respectively), Trichoptera larvae: Lepidostomatidae and Limnephilidae (10.2 and $18.4 \%$ respectively), and Diptera larvae: Procladius sp. Skuse (6.1\%).

The majority of biodiversity indices ( $\left.\mathrm{H}^{\prime}\right)$ ranged from an average of 1.5 to 3.5 (Fig. 3c). A significantly departing value of H' index at R3 site was an exception; at this site we recorded a relatively low density and a small number of taxa and the prevailing representatives of the Enchytraeidae family accounted for $71 \%$ of the share in total density.

\section{The Impact of Environmental Factors on Distribution and Abundance of Macroinvertebrates}

Results of the CCA showed that the density of specific taxa is significantly $(p<0.005)$ influenced by ammonium ions, orthophosphates, water temperature and water velocity (Fig. 4a). A high level of ammonium ions impacts the density of: Aelosomatidae, Triaenodes McLachlan, and Planorbis carinatus O.F.M (Fig. 4a), which was observed at KH2 site (Fig. 4a). The highest temperature correlated with high orthophosphate content and water flow velocity significantly contributes $(\mathrm{p}<0.005)$ to higher density of, among others mainly Chironomidae, as well as Chaetogaster sp., Gammarus roeselli, Bithynia tentaculata and Asellus aquaticus (Fig. 4a). This was confirmed for site No. 1 on the River Płonia (P1) and all sites on the Rivers Rurzyca and Tywa (4b).

\section{Discussion}

The study sites were observed to be highly diversified in terms of physico-chemical, hydrological and biotic parameters. The results of physico-chemical parameter analysis of waters in the studied rivers were assessed in accordance with the Regulation of the Minister of Environment of 21 July 2016 on the classification method for the condition of uniform bodies of surface waters and environmental quality standards for the priority substances of non-class water. The low quality of these waters was mainly determined by average dissolved oxygen rates, nutrient content and high water conductivity rates. Water flow velocity rates in the studied watercourses were usually comparable to those 

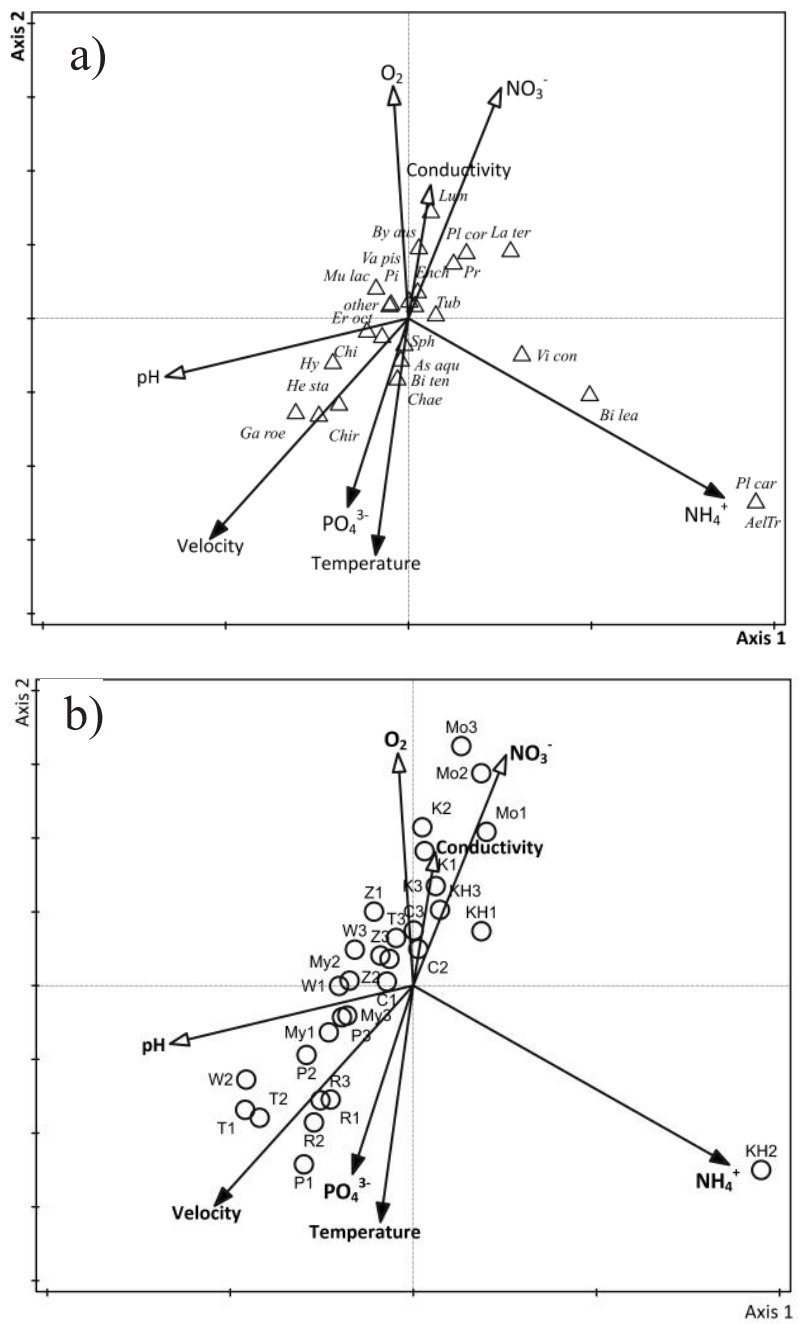

Fig. 4. CCA of the assessment of impact of physico-chemical parameters on density of specific taxa a) at the studied sites b). Variables with senses of the vectors marked are statistically significant for biodiversity in the set. In total, these variables account for $34.3 \%$ of total variability. Ael-Aelosomatidae, Ench- Enchytraeidae, Lum-Lumbriculidae, Chae-Chaetogaster, Tub- Tubificidae, Er oct- Erpobdella octooculata, He sta- Helobdella stagnalis, As aqu- Asellus aquaticus, Ga roe- Gammarus roeselli, Hy- Hydropsyche, Tr- Triaenodes, Chir- Chironomidae, Chi- Chironomus, Pr- Procladius, By aus-Bythinella austriaca, Bi lea-Bithynia leachi, Bi tenBithynia tentaculata, La ter- Ladislavella terebra, Pl carPlanorbis carinatus, Pl cor-Planorbis corneus, Vi con-Viviparus contectus, Va pis- Valvata piscinalis, Mu lac-Musculium lacustre, Pi-Pisidium, Sph-Sphaerium, other-organisms whose share in the density was less than $1 \%$. Descriptions as in Table 1.

recorded for rivers located in the lowlands (due to the terrain), and the only higher water flow velocity rate was recorded on the Wardynka River, which is characteristic of mountain streams [18-19]. Small watercourses are highly unstable in terms of water flow rates [18], whereas differences in physico-chemical parameters are probably due to the increasing anthropogenic impact $[2,10]$; this is the reason for the recorded discrepancies between studied watercourses and sites. Bearing in mind that both physico-chemical factors and the intensity of anthropoppression in small watercourses are indirectly dependent on temperature, it can be assumed that these changes depend on seasonality.

Large discrepancies between the sites and watercourses were also observed while analysing the composition and density of the benthic communities, as well as Shannon's diversity index (H'). The total of 95 taxa were identified, including 49 species belonging to the following classes: Oligochaeta, Bivalvia, Insecta, Gastropoda, Crustacea, and Hirudinea, as well as Enthognatha and Desmospongiae. The observed biodiversity and density of benthic communities as well as biodiversity indices are typical of small watercourses found in Poland [7] and other countries [20-22]. It should be stressed that the majority of macrobenthic species encountered in each river are eurytopic: they can dwell within a wide range of environmental parameters, thus they perform poorly in saprobic classification. Stenotopic species occur only in the River Wardynka (W2), which is similar to mountain rivers. The European Water Framework Directive requires that member states assess all their surface waters based on a number of biological elements, including macroinvertebrates. In EU member states, a number of different indicators of water quality assessment have been created, which due to environmental preferences, climatic variations and species diversity of particular countries are characterised by different parameters of the assessment indices.

The observed diversification of macrobenthic community structures in the majority of small watercourses, with clear dominance of taxa tolerant of environmental pollutions, may result from a set of components related to water chemistry [23-24], bottom type and its composition [14], as well as the composition and presence of macrophytes [25]. In our study, we found that of all analysed environmental parameters, ammonium ions, orthophosphates, water temperature and water velocity had the strongest impact on the occurrence and density of some taxa. Furthermore, research investigating small watercourses in Europe, which has been conducted, has shown that water temperature and velocity are major determinants of the benthic invertebrate community structure [26-27].

At the sites where high content of orthophosphates, ammonium ions, high temperature and high water velocities were observed, the mainly occurring species were: Chironomidae spp., Chaetogaster sp., Bithynia tentaculata and Asellus aquaticus, which often prevail even in polluted watercourses [28]. Błachuta et al. [29] construes that the high density of the abovementioned taxa is possible precisely in the case of high concentrations of phosphates and ammonium ions due to their capacity to survive even when water is severely polluted.

In our study, phosphate ions, ammonium ions, water temperature and velocity accounted for as many as $34.3 \%$ of the variations in the set. The remaining variations may be searched for, among others, in biotic components. The studied watercourses were 
inhabited by fish, and some researchers [24, 30] claim that fish predation impacts the structure and density of invertebrate communities in the watercourses. Nicola et al. [23], however, stated that benthic communities are more affected by physico-chemical properties of the watercourse rather than by fish predation. Traversetti et al. [25] on the other hand, suggests that composition and density of benthic communities is determined by the degree of coverage of the composition of the bottom and macrophytes. In our work, we have not studied the effect of macrophytes on macrobenthic communities so far, which will be carried out in the future.

\section{Conclusions}

The study results revealed that the composition and structure of benthic communities was typical of small watercourses found in Central Europe. As in other countries, small watercourses in Poland are susceptible to any environmental changes (seasonal and anthropogenic). In the majority of sites, eurytopic species were prevalent; stenotypic species dominated only at one of the sites on the River Wardynka. Results of the CCA showed that discrepancies with regard to composition, density and Shannon's diversity index $\left(\mathrm{H}^{\prime}\right)$ most probably is influenced by ammonium ions, orthophosphate ions, water temperature and water velocity. The high temperature of the water together with high orthophosphate content and water flow velocity significantly impacts such eurytopic species as: Chironomidae, Chaetogaster sp., Gammarus roeselli, Bithynia tentaculata and Asellus aquaticus. Ammonium ion content on the other hand, has a significant impact on increased density of Aelosomatidae, Triaenodes McLachlan, and Planorbis carinatus O.F.M.

\section{Acknowledgements}

This study was supported by the implementation of the multi-annual programme "Technology and environmental projects supporting innovative, effective and low-pollution management of resources in rural areas", Task No. 5 "Knowledge support of the preparation, implementation and approval of works intended to maintain land reclamation equipment".

\section{Conflict of Interest}

The authors declare no conflict of interest.

\section{References}

1. ORLIŃSKA-WOZNIAK P., WILK P., GĘBALA J. Water availability in reference to water needs in Poland. Meteorol. Hydrol. Water Manage. 1 (1), 45, 2013.
2. KANIECKI A. Environmental changes in the Warta valley within the Poznań area connected with anthropo-pressure. Landform Analysis 24, 23, 2013 [In Polish].

3. ADÁMEK Z., KONEČNÁ J., PODHRÁZSKÁ J., VŠETIČKOVÁ L., JURAJDOVÁ Z. Response of SmallStream Biota to Sudden Flow Pulses Following Extreme Precipitation Events. Pol. J. Environ. Stud. 25 (2), 495, 2016.

4. BIS B., MIKULEC A. Guide to assessment the ecological status of rivers based on benthic macroinvertebrates. Biblioteka Monitoringu Środowiska, Warszawa, Poland, 121, 2013 [In Polish].

5. EUROPEAN COMMISSION: Introduction to the New EU Water Framework Directive. (Available at: http://ec.europa. eu/environment/water/water-framework/info/intro_en.htm) 2016.

6. CAPITULO A.R., TANGORRA A., OCÓN K. Use of benthic macroinvertebrates to assess the biological status of Pampean streams in Argentina. Aquat. Ecol. 35, 109, 2001.

7. KRÓLAK E., KORYCIŃSKA M. Taxonomic composition of macroinvertebrates in the River

8. Liwiec and its tributaries (Central and Eastern Poland) on the basis of chosen physical and chemical parameters of water and season. Pol. J. Environ. Stud. 17 (1), 39, 2008.

9. ROSENBERG D.M., RESH V.H. Freshwater biomonitoring and benthic macroinvertebrates. Chapman and Hall, New York, 488, 1993.

10. BIS B, ZDANOWICZ A, ZALEWSKI M. Effects of catchment properties on hydro-chemistry, habitat complexity and invertebrate community structure in a lowland river. Hydrobiologia, 422/423, 369, 2000.

11. ADÁMEK Z., KONEČNÁ J., PODHRÁZSKÁ J., VŠETIČKOVÁ L., JURAJDOVÁ Z. Response of SmallStream Biota to Sudden Flow Pulses Following Extreme Precipitation Events. Pol. J. Environ. Stud. 25 (2), 495, 2016.

12. PAKULNICKA J., BUCZYŃSKI P., DĄBKOWSKI P., BUCZYŃSKA E., STĘPIEŃ E., SZLAUERŁUKASZEWSKA A., ZAWAL A. Development of fauna of water beetles (Coleoptera) in waters bodies of a river valley - habitat factors, landscape and geomorphology. Knowl. Manag. Aquat. Ec. 417, 40, 2016.

13. JURAJDA P., ADÁMEK Z., JANÁČ M., VALOVÁ Z. Longitudinal patterns in fish and macrozoobenthos assemblages reflect degradation of water quality and physical habitat in the Bílina river basin. Czech J. Anim. Sci. 55 (3), 123, 2010.

14. OBOLEWSKI K.T., GLIŃSKA-LEWCZUK K., KOBUS $\mathrm{S}$. The effect of flow on the macrozoobenthos structure in a re-opened oxbow lake: a case study of the River Słupia, northern Poland. Ecohydrology of Surface and Groundwater Dependent Systems: Concepts, Methods and Recent Developments. Eds. Thoms M., Heal K., Bøgh E., Chambel A. and Smakhtin V., IAHS Publ. 328, 13, 2009.

15. YU Z., WANG H., WANG R., HE T., CAO Q., WANG Y., LIU J. The Effects of Bridge Abutments on the Benthic Macroinvertebrate Community. Polish J. Environ. Stud. 25 (3), 1331, 2016.

16. KORYCIŃSKA M, KRÓLAK E. The use of various biotic indices for evaluation of water quality in the lowland rivers of Poland (Exemplified by the River Liwiec). Polish J. Environ. Stud. 15, 419, 2006.

17. OBOLEWSKI K., GLIŃSKA-LEWCZUK K., JARZĄB N., BURANDT P., KOBUS S., KUJAWA R., OKRUSZKO T., GRABOWSKA M., LEW S., GOŹDZIEJEWSKA A., 
SKRZYPCZAK A. Benthic Invertebrates in Floodplain Lakes of a Polish River: Structure and Biodiversity Analyses in Relation to Hydrological Conditions. Pol. J. Environ. Stud. 23 (5), 1679, 2014.

18. BRAAK C.J.F TER, ŠMILAUER P. Canoco reference manual and user's guide: software for ordination (version 5.0). Microcomputer Power (Ithaca, NY, USA), 2012.

19. KÄNDLER M., SEIDLER C. Influence of hydrological situations on benthic organisms in a small river in Saxony (Germany). J. Hydrol. Hydromech. 61 (3), 188, 2013

20. STRUŻYŃSKI A., BARTNIK W., KULESZA K., CZOCH $\mathrm{K}$. Hydrodynamic balance as an important parameter influencing the ecological status of Carpathian Rivers. Annual Set The Environment Protection, 15, 2591, 2013 [In Polish].

21. BINDER W., GÖTTLE A., SHUHUAI D. Ecological restoration of small water courses, experiences from Germany and from projects in Beijing. International Soil and Water Conservation Research, 3 (2), 141, 2015.

22. YANYGINA L.V. Macrozoobenthos as an indicator of the ecological state of mountain watercourses. Russ. J. Ecol. 48 (2), 185, 2017.

23. VIŠINSKIENÉ G., BERNOTIENÉ R. The use of benthic macroinvertebrate families for river quality assessment in Lithuania. Cent. Eur. J. Biol. 7 (4), 741, 2012.

24. NICOLA G.G, ALMODÓVAR A, ELVIRA B. Effects of environmental factors and predation on benthic communities in headwater streams. Aquatic Sciences $\mathbf{7 2}$ (4), 419, 2010.
25. KREPSKI T., CZERNIAWSKI R. Shaping of macroinvertebrate structures in a small fishless lowland stream exposed to anthropopressure, including the environmental conditions. Knowl. Manag. Aquat. Ecosyst. 419, 19, 2018.

26. TRAVERSETTI L, CESCHIN S, MANFRIN A, SCALICI M. Co-occurrence between macrophytes and macroinvertebrates: Towards a new approach for the running waters quality evaluation? J. Limnology 74, 133, 2015.

27. ANDRIANOVA A.V. Biotic indices and metrics in assessment of the water quality of small rivers on the territory of Ergaki Nature Park (South of Krasnoyarsk Krai). Contemp. Probl. Ecol. 8 (3), 358, 2015.

28. GROLL M. Relations between the microscale riverbed morphology and the macrozoobenthos - implications for the ecological quality assessment and the definition of reference conditions. Int. J. Environ. Impacts, 1 (3) 375, 2018.

29. DURAN M. Monitoring Water Quality Using Benthic Macroinvertebrates and Physicochemical Parameters of Behzat Stream in Turkey. Pol. J. Environ. Stud. 15 (5), 709, 2006.

30. BŁACHUTA J., SZOSZKIEWICZ K., GEBLER D., SCHNEIDER S. How do environmental parameters relate to macroinvertebrate metrics? - prospects for river water quality assessment. Pol. J. Ecol. 62, 111, 2014.

31. DOMAGAŁA J., KREPSKI T., CZERNIAWSKI R., PILECKA-RAPACZ M. Prey availability and selective feeding of sea trout (Salmo trutta L., 1758) fry stocked in small forest streams. J. Appl. Ichthyol. 31, 375, 2015. 